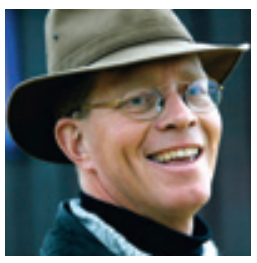

\title{
Ved Rikets port
}

\section{Å vente på en transplantasjon er en underlig øvelse.}

Sykkelprøven og førerprøven bestod jeg med glans. Men hva hjelper vel det når man stryker på blodprøven. I blodet står det skrevet hvordan ens indre tilstand arter seg. Blodet lyver aldri, blir det sagt. Den første dårlige nyheten var i mitt tilfelle at nyrene ikke lenger virket som de skulle. Den neste dårlige nyheten var at nyrene er mer enn halvveis ødelagt når avtagende funksjon kan registreres ved en blodprøve. Det er som om flyalarmen først skulle gå når halve landet allerede er okkupert.

Jeg har alltid ønsket meg en søster. Men så fikk jeg cyster isteden. Hvilket har forsterket mitt på forhånd anstrengte forhold til norsk sidemål. Sykdommen består i at nyrene begynner å blåse ballonger helt av seg selv, aldeles uten at noen feiring eller festivitas er i sikte. Til slutt tok ballongene i mitt tilfelle så stor plass at nyrene ikke fikk gjort mer enn ti prosent av jobben sin. Derfor ble jeg ferdig utredet for transplantasjon i 2006. Så var det bare å vente med to esende fostre av noen nyrer i magen. Over fire kilo skulle de til sammen komme til å veie, med permanente gravideplager som resultat.

Ventetiden er ofte det verste. Jeg husker tydelig at disse ordene stod skrevet med fete bokstaver i Soldathåndboken den gang jeg var rede til å gi mitt liv for Norge. Som følge av at ventetiden er det verste, har militæret organisert seg slik at nesten alle må vente hele tiden. De fleste køer i alle samfunn oppstår foran goder som staten er alene om å tilby. Derfor har vi opplevd slike ting som telefonkø, polkø, helsekø og bilkø.

Vi venter, alle sammen, på brevet som skal forandre vårt liv, lottorekken som skal gå inn og begivenheten som skal rette opp alt det skjeve. Min kone ble i ventetiden utredet og erklært som aktuell donor. Sammen ventet vi i mer enn to år på at noen skulle si vi kunne begynne å vente på brevet som ville opplyse om dag og klokkeslett for den forestående operasjonen. Brevet kom ikke, som forespeilet, i desember. Hver dag gikk vi til postkassen med håp og frykt flettet i hverandre. Forgjeves. Brevet kom heller ikke januar.

Moren til forlagsmannen Brikt Jensen ventet hver dag på at postbudet skulle komme med brevet fra hennes store kjærlighet. Til slutt orket ikke postbudet lenger å betrakte den forsmåddes skuffelse. Han tok seg sammen og skrev selv det kjærlighetsbrevet hun ventet på. Postbudet og den ventende kvinnen skulle i tidens fylde bli Brikt Jensens foreldre. «Og så skulle man ikke ta seg tid til å vente på postbudet,» skriver sønnen i en av sine bøker.

Vårt brev kom først i slutten av februar. Der stod det at vi skulle innlegges ved Rikshospitalet 14. april og at transplantasjon ville finne sted den 16. Etter 46 forberedende timer på Rikshospitalet skulle min kone og jeg trilles inn til narkose da kirurgene avblåste operasjonen og ba oss reise hjem. $\mathrm{Vi}$ var blitt dusjet med desinfiserende midler, barbert i de aktuelle operasjonsområder og lagt i sterile operasjonsklær. De hadde gitt oss innsovningspiller, vekket meg klokken fire om natten for en siste kaliumblodprøve og gitt min elskverdige donor blodfortynnende sprøyte. For første gang siden innleggelsesbrevet forelå hadde vi halv åtte om morgenen den 16. april funnet en slags ro og innforlivet oss med det forestående. Da alt sammen på et blunk ble avblåst.

Det lar seg forstå at plutselig oppdukkende organer fra nylig avdøde må gis forrang. Ikke fullt så lett var det å akseptere at ens egen transplantasjon måtte utsettes i 11 døgn. Ganske særlig ikke når flere pleiere ved avdelingen med stolthet hadde fortalt at man nylig gjennomførte 14 uforutsette transplantasjoner i løpet av en enkelt helg uten å forskyve noen av de planlagte. Sykehuset må antas å vite at ventetiden ofte oppleves som den største påkjenningen for mennesker som venter på store kirurgiske inngrep. Uro, redsel og søvnløshet preger dagene og ukene i forkant. Familie, venner, naboer og ikke minst ens barn blir sterkt involvert. Intrikate puslespill blir lagt for å få dagliglivet til å fungere i ens fravær.

Helsevesenet vil gjerne motivere flere mennesker til å stille opp som givere av nyrer. Da er det ikke forstandig å opptre slik man gjorde i vårt tilfelle. Jeg har ingen innvendinger mot hvordan jeg selv er blitt behandlet. Sveklinger har man i vårt samfunn hevd på å behandle slik man lyster. Langt mer bekymret er jeg for de prøvelser min donor er blitt utsatt for. Ikke bare redder hun mitt liv. Indirekte redder hun også livet til en annen ved å forkorte ventelisten på nekronyrer. En levende donor kan visstnok spare samfunnet for mer en ti millioner kroner i dialyseutgifter.

Hun burde bli båret på gullstol. Isteden følte hun seg ved hjemsendelsen rubrisert som en rettighetsløs ansamling av blod og vev. Så lav er den levende givers posisjon at hvis hun var død, ville transplantasjonen blitt utført til avtalt tid. Denne visshet føltes i 11 døgn vondere å bære enn allverdens sting i mellomgulvet. Nesten like vond som uvissheten om hva vi hadde $i$ vente ved vår neste innleggelse på hospitalet.

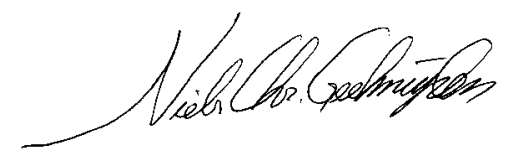

\section{I neste nummer:}

Påskeøya

Kampen mot tuberkulose

Fødsel ved seteleie
Narkosedybde

Creutzfeldt-Jakobs sykdom

Kostnader ved MR 